\title{
Model of Development Students' Softskill With Credit System by Integration of Academic and Student's Activities in ORMAWA Activity
}

\author{
Armida. $\mathrm{S}^{* 1}$, Yuhendri LV \\ \#Economics Faculty, Universitas Negeri Padang \\ Prof Hamka Street, Air Tawar, Padang, West Sumatera, \\ Indonesia \\ ${ }^{1}$ mimiasriel@gmail.com, yvrista@gmail.com
}

\author{
Ramhat Richard \\ \#Economics Faculty, Universitas Riau \\ ${ }^{1}$ richard.armida@yahoo.com
}

\begin{abstract}
Challenges of education organized is the graduates are absorbed in the world of work with the appropriate quality of the standards of careers. The graduates are faced with competition among universities in the country and abroad in line with the Asean Economic Community (AEC). Efforts to improve student achievement in academic and non-academic is generally driven by the policy in UNP that of each graduates Padang State University will be awarded a Certificate of Companion Certificate (SKPI) since 2014. This SKPI is given to graduates of the State University of Padang in accordance with current working conditions that requires more soft skills than hard skills. This study aims to visually design Development System Credit of Student Soft skill (SKPSM) that encourage students to actively engage and compete in the areas of reasoning, aptitude interest and dedication. Activities are done in a balanced will sharpen and strengthen the mental, physical and rational thought students. Determination Policy Development System Credit of student Soft skill (SKPSM) aims to encourage student involvement in non-academic and support academic achievement, in accordance with the vision and mission of Education Economics program, Faculty of Economics University of Padang. The results of this research showed that model of development students' soft skill with credit system by integration of academic and student activities In ORMAWA activity that constructed in the implementation of the program with a systematic, comprehensive and integrated. Recommendations for economic education program (PSPE) to synergize between hard skills with soft skills and how the transmission hasn't compulsion for both lecturers and students. And not an expense of credits that has so much in Higher Education. One way is by making transmission of soft skills in Hidden Curriculum, through the presentation of several topics in courses taught by lecturers who are integrated in the activities of student organizations, both extra-curricular activities or curricular.
\end{abstract}

Keywords-Model Of Development, Students Soft skill, Credit System

\section{INTRODUCTION}

Competence of graduates is one factor of college success in its mission. It is associated with the attraction (pull factor) for the users (stakeholders) to wear college graduates who have the best competence. [1]. Climate conducive academic will successfully give birth to individuals ideal student who has the ability to balance between hard skills and soft skills, but in fact based on the tracer study [2] conducted by several studies program at the State University of Padang since 2014-2015, concluded despite the end user satisfied with the technical skills (hard skills) owned by the alumni of the UNP and rated loyal, willing to develop themselves, and not easy to complain. However, there are some categories that have less votes is confidence, leadership, communication, discipline and cooperation with the team.

The demands adequate of soft skills from the industrial world: the reality of the social and cultural environment of students who are currently more likely to lead to permisivisme, consumerism and instant culture. This is supported by data from the tracer study [2] (2014) and advice from Prof Agus Rahayu (2015) accreditation assessors PSPE which leads to the conclusion that the development of soft skills would be more productive if their activities are more focused and intensified. Productivity development of soft skills should be well planned integrated between student affairs and academic fields.

The different needs and development as well as the viewpoints of the hard skills and soft skills among the workforce / business and universities at this time according to the results of searches and studies [3] (Illah Sailah, 2008) are as follows:

1. The ratio needs of soft skills and hard skills in the world of work / effort is inversely proportional to its development in college. Success in the world of work / business $80 \%$ is determined by the mind set (soft skills) owned and $20 \%$ is determined by the technical skills (hard skills). But in practice our current education system, especially in college, serving the development of soft skills is only given an average of $10 \%$ in its curriculum, while $90 \%$ of them contain hard skills.

2. The views of the graduate college "high competence" is a graduate with a high GPA and pass in a short 
time ( $<4$ years). While the industry stated that the definition of graduates that "high competence" is those who have skills in the technical aspect and a good attitude. A study programs expressed either by the college, if graduates have a short waiting time to get a first job, but the industry says is not that, but how tough a graduate to have a commitment to the agreements that have been made on the first job.

Likewise at the state university of Padang, the problem there is a disparity between the needs of users graduate to the preparation of graduates in the UNP, in terms of soft skills and hard skills., The process of education in the UNP has not been synergy between soft skills and hard skills well, while the number of credit units students are quite a lot and learning methods of soft skills in the UNP has not been integrated in the activities of academic and student in building academic atmosphere as the basic character for the philosophy of the Real Campus working world the weakness of students PSPE and graduate PSPE are: a) the ability of leadership, b) the ability of communication, c) discipline d) teamwork, and e) lack of confidence. These conditions would be a concern for the study program to follow up that the competence acquired by graduates in accordance with user expectations. The level of competition in the business world is no longer local, but regional and even international.

To answer the question of how the University is able to develop the hard skills and soft skills in a planned, synergies and systematically while the number of credit units students had enough, this research tried to construct the design development of soft skills of students with a credit system at a much more oriented to the life of a student as a point early or subjects that enable the development of soft skills to run optimally, planned and integrated.[4]

Improving the quality of graduates, in addition to be done through a learning system that is comprehensive, effective and transformative, also developed program student guidance in improving the knowledge (cognitive), attitudes (affective) and skills (psychomotor) so as to provide values added to improve competitiveness graduates in accelerating the achievement of the vision, mission and objectives of the study program.[5]

\section{RESEARCH METHODOLOGY}

This research is a descriptive study using a combination of quantitative and qualitative approaches. The incorporation of these two methods will provide a deeper understanding of the object under study, especially in issues related to human attitudes and behavior. [6].

Research on the development of soft skills of students in PSPE in the Research and Development consists of three cycles: (1) To identify the needs of the target respondents (2) the preparation of extra curriculum development of soft skills of students with the integration of academic and student affairs with the credit system (3) recommended the policy in the form of soft skills development model student with a credit system

Specifically, the data analysis performed using a variety of methods in accordance with the objectives to be achieve. Technique of analyzed using test by SPSS (Statistical
Package for Social Science). The test results are then summed to prove the effectiveness of soft skills development model student with a credit system. As for analyzing the effectiveness of the development model of the development of soft skills of students in order to increase student achievement in PSPE, [7] used a simple statistical methods, that is

\section{$\mathrm{R}$}

The effectiveness of the program $=-$ x $100 \ldots .(1)$.

$\mathrm{T}$

The effectiveness of this training program can be seen from the following variable
a. Target Accuracy Program
b. Orientation Program
c. Program Objectives
d. Model / format used
e. Documentation development model

Effectiveness was measured by using reference standards in line with[8] Litbang Depdagri as shown in Table I

Table I. MEASURES OF EFFECTIVENESS ACCORDING REFERENCE LITBANG DEPDAGRI

\begin{tabular}{|c|c|}
\hline Effectiveness Ratio & Attainments \\
\hline under 40 & Highly Ineffective \\
\hline $40-59,99$ & Ineffective \\
\hline $60-79,99$ & Effective Enough \\
\hline Above 80 & Very Effective \\
\hline
\end{tabular}

Source: Litbang Depdagri, 1991

\section{RESEARCH RESULTS AND THEIR DISCUSSION}

The curriculum is an implementation of university autonomy. So it can be developed by universities in accordance with the needs and demands of a changing environment. Curriculum approach would be most effective if supported by the system and learning methods appropriate and adequate facilities. There are several alternatives in implementing the education and training of soft skills are integrated in the curriculum of the following: 1. Insert the material soft skills as an integral part with a variety of other materials presented in the curriculum. 2. Presenting courses Character Development (character building) in the first to IV cemester, are obliged to travel by non credits. 3. Integrating the evaluation of soft skills of students with learning evaluation system in fortofolio students or through extra curriculum approach, where students soft skills honed in various forms of integrated activities in units of student activities (SMEs) and student organizations that exist. Some colleges implement this approach by requiring students to be active in extra-curricular activities at all-time studies. At the end of his studies, before an exam essay, students submit a self-evaluation that is made under the supervision of an academic supervisor. The results of self-evaluation that has been qualified, a prerequisite thesis examination. This approach is not an alternative of some previous approaches. But this is precisely supporting over other approaches being used. Here is a test for the organization functions effectiveness universities to create the right atmosphere for the development 
of soft skills and hard skills of students. Academic atmosphere into a field a good learning experience for students, with the look, feel, and proved immediately good practices (best practices) when interacting with fellow students, staff, faculty, and leaders of the institution. Therefore, the institutions that poor academic atmosphere, will give you an example of poor soft skills for students. Attitudes and behavior of teachers, employees, leaders in campus activities of daily visits by the students as a concrete example, and obviously will affect the quality of learning by doing them.

\section{Design Development Soft skill}

Higher education became one of the spearheads in the context of the creation of the nation's competitiveness through its products. Among them is the quality of the resources generated from the learning process is organized in higher education. The world needs graduates who are able to fulfill their tasks and responsibilities based on creativity and initiative, in addition to academic competence. To accomplish this, universities must develop a learning system that can balance the soft skills and hard skills.[9]

These demands can be met through the approach of the curriculum, extra curriculum, and the creation of an academic atmosphere that is conducive to the development of student character. The purpose of teaching and learning in higher education has been widespread across the spectrum, from factual knowledge-based disciplines to think critically, and of moral and ethical behavior to citizen awareness, and this is the essential purpose of teaching in higher education. In other words, students must obtain soft skills on campus, either through its own learning or integrated with other subjects, as well as interaction in the real campus life(theRealCampus).

Plan Development Program student soft skills done in phases [10]:

\section{1) Drafting}

Study Program in conducting this development begins with soft skills needs survey in the industry. This is done to further focuses soft skills what the student will be strengthened in accordance with user needs graduates. [11]. The survey results demonstrate the need soft skills graduates, that graduates of Economic Education Program requires the strengthening of soft skills in the field (1). Communication, (2). Cooperation, (3). Discipline, (4). Troubleshooting, and (5). Confidence.

Development of soft skills built up so that students in the program implementation can be done in a systematic, comprehensive, integrated and continuitas. Systematic, means the development of soft skills by using the system, namely the activities undertaken included input, the process is carried out in stages to produce output. Comprehensive, namely the development of soft skills performed by the entire academic community, students, teachers and education personnel. Joined entire community will contribute to the commitment to implement the soft skills development program that can be run according to plan. Integrative, is soft skills development process is done in stages where one stage and the next stage is not a stand-alone, but support each other in order to be able to create a synergy that will produce more value.

Integration also occurred in the implementation of the development of soft skills that are not solely of shared responsibility. Sustainable, it in practice, soft skills development implemented in phases, starting from the introduction stage, followed by a phase of growth and ends with the stage of maturation. [12]. Phasing on an ongoing basis is a crucial process to soft skills development of students with no overlap or even missed, with attention to the psychological development of soft skills Development Stages students. Development of softskils students, namely:

1.a. introduction stage, or the introduction stage Private (seft management)

This stage is focusing on soft skills fundamental attributes, such as being able to recognize themselves, the purpose of life and the environment. The introduction phase is primarily intended for first-year students $\left(1^{\text {rd }}-2^{\text {rd }}\right.$ Semesters $)$. As new students need to make adjustments so that it can survive in its new environment. This program will create a new student is able to identify themselves at the same environment, so that will be able to manage ability in him in an effort to be a superior individual.

1.b. The growth phase or stage of Building Relationships

This stage is mainly addressed to students in the second year $\left(3^{\text {rd }}-4^{\text {rd }}\right.$ semesters $)$. At this stage there is a tendency of students begin to live a more intimate activities of interaction with the environment. By doing the above actualizing its potential, students are expected to have built itself into a human being independent and mature.

1.c. Stage Building Network (Social-Networking)

Maturation stage or stages Building Network is mainly aimed at students of third and fourth year $\left(5^{\text {rd }}-8^{\text {rd }}\right.$ semesters). This stage is the stage where the student has to have the introduction of more intimate environment. It is characterized by the mastery of information and social networking (social network) which is already quite extensive. At this stage the students were more directed concentrated on efforts to resolve his studies and began to mobilize attention to the labor market will be entered later.

\section{2) Implementation Phase}

The implementation phase is advanced stage after the design phase is done. At this stage, the role of the Academic Advisors are needed in efforts to optimize the program. Each Academic Advisors, given access to monitor the achievement of students who become a point soft skills academic guidance online. Students will upload the document achievement of activities that have been implemented, so that the document verification will be conducted by the Academic Advisors or assisted by the Student Council. Integration of Academic and Student Affairs in the implementation of development soft skills divided into three aspects, namely: (1) Elements of Reasoning, (2) Elements Talent Interests, (3) Elements of Community Service 


\section{2.a. Elements of Reasoning}

In every element that is developed will be given points based on the level or levels of achievement. Here are the components of the development of the Elements Reasoning, namely: (a) Essay, (b) advanced search Scientific Information, (c) Intern, (d) Involvement in the Seminar / Workshop / Lecture / Public Lecture, (e) Increase in Foreign Language, (f) Assistance, (g) Company Visit, (h) Preparatory Activities Graduation, (personality development)

\section{2.b. The interest element of talent}

Talent Development Interests elements developed in many student activities Student Organization. Here is an activity that was developed from elements of Talent Interests, namely: (a) Competition, (b) entrepreneurship Student Expo, (c) Fostering Talent \& Interests, (d) Shown in activities, (e) LKMM- Up-Grading Student Organization, TDMO (f) campus orientation activities. In the implementation of soft skills development program is divided into compulsory and elective activities. Here is one example of a component of the activities, the assessment, the unit in question, the nature, the points and the status of the assessment element design examples Interests Talent for talent interests rated.[13]

2.c.The element of Community Service

Elements assessed on Community Service elements are (1) the Committee, (2) Internship (Internal), (3) External Organizations Membership, (4) Social Service / Other service activities, (4) Ceremony.

Support SKPSM of the achievements of the Strategic Plan Study Program, intended many more student achievements both in the number and level of competition is very helping PS Economic Education in achieving the strategic plan of study program. That student achievement will be more and more at the international level as one of the indicators of success in achieving graduates who are competitive and global perspective. Student achievement earned him not only at the provincial or national level, but also recognized at the international level.[14].

\section{3) Monitoring and Evaluation Phase}

Monitoring and evaluation stage is the stage of monitoring the achievement point soft skills. Monitoring is done in stages by several related units, is Student Affairs and Studies Program. Students can print their own results soft skills collection points or obtain information online.

\section{CONCLUSION}

Based on the results of the tracer study of 2014 graduates showed that user satisfaction excellence Economics Bachelor of Education graduates PS FE UNP is loved her job and tend not to like to move jobs, it is proved by the low level of the first job obtained graduates as temporary work, and even tended very obedient to the rules of the company. Based on the condition of graduates and the needs of the user. [15]. Soft skills development of students PSPE constructed such that in the implementation of the program can be done in a systematic, comprehensive and integrated. Systematically, it means the development of soft skills by using the system, namely the activities undertaken included input, the process is carried out in stages to produce an output. Comprehensive, namely the development of soft skills performed by the entire academic community, students, teachers and education personnel. Joined entire community will contribute to the commitment to implement the soft skills development program that can be run according to plan. Integrative, is soft skills development process is done in stages where one stage and the next stage is not a stand-alone, but support each other in order to be able to create a synergy that will produce more value. Integration also occurred in the implementation of the development of soft skills that are not solely of shared responsibility. Sustainable, is in practice, soft skills development implemented in phases, starting from the introduction stage, followed by a phase of growth and ends with the stage of maturation.

Synergy between hard skills with soft skills and how to be transmitted does not feel any compulsion for both lecturers and students. [16]. And not an expense credits that has so much in Higher Education, One way is to conduct soft skills transmission through the Hidden Curriculum, through the presentation of several topics in courses taught by lecturers and activities to be implemented in student organizations. Fostering student and lecturer of the course are advised to be able to integrate soft skill in the learning process and help students implement in student organizations either curricular or extra curricular activities. These soft skills instead of rote material but is practiced by people who study or who want to develop.

\section{ACKNOWLEDGMENTS}

Thanks are due to Rector of State University of Padang, Prof. Ganefri have supported us to participate in this conference, Thank you.

\section{REFERENCES}

[1] Putri, Rinella. Artikel berjudul : "Pentingnya Soft Skill". Situs:http://www.vibiznews.com (diakses pada 10 januari 2012).

[2] Armida dkk. Laporan Tracer Study PSPE FE UNP. 2014

[3] Saillah Illah, "Pengembangan soft skills dan implementasi KBK serta proses pembelajaran di Perguruan Tinggi”; Mei 2008, http://www.isailah.50webs.com/

[4] Kuswara Heri. Materi Seminar Soft Skill Berjudul: "Pentingnya Soft Skill dalam Meraih Karier Gemilang", Oktober 2014, Bina Sarana Informatika

[5] LIA Jakarta; 29 Februari 2012; http://stbalia.ac.id/ Krisna. "FTSL Mewajibkan Calon Wisudawan Lulus Penyusun Tim, "di UNS Ekskul Masuk Transkrip Nilai-Loh"; Juni 2015; http://news.okezone.com

[6] Basith, A. 2004. Berani Sukses. PT. Grhadika. Jakarta.

[7] Santoso Slamet, "Softskills di perkuliahan, qouvadis..?? Integrasi Soft Skill Mahasiwa di Perkuliahan; Langkah letih Pengembangan dan Pendekatan Pendidikan di PT"; 2009, ttp://www.bisesagroup.com

[8] Litbang Depdagri.1991. Pengukuran Efektivitas Kinerja.Jakarta

[9] Klaus, P. 2007. The Hard Truth about Soft Skills. Harper Collins Publisher. New York

[10] Kapp M. K.,\& Hamilton, B. (2006). White paper: Designing Instruction to Teach Principles (soft skill). Institut for Interactive Technologies. Diambil pada 2 September 2015, dari http//wwwKarkapp.com/ materials/teaching\%20Principles Pdf. 
[11] Shaheen Majid, Zhang Liming, Shen Tong, Siti Raihana Nanyang Technological University, Singapore Importance of Soft Skills for Education and Career Success International Journal for CrossDisciplinary Subjects in Education (IJCDSE), Special Issue Volume 2 Issue 2, 2012

[12] Elfindri dkk, Softskills pendidik, 2015, makalah dalam kegiatan workshop penyususnan kurikulum KKNI FE UNP

[13] Prijosaksono, A., dan P. Hartono. 2002. Make Yourself A Leader. Penerbit Elex Media Komputindo. Jakarta.

[14] Lt.P.KARTHI. , MS.S.N.MAHALAKSHMI. SOFTSKILLS THROUGH ELT CLASSROOMS.Research Scholar, Research and Development Centre,Bharathiar University,Coimbatore\& Assistant Professor of English,Gobi Arts and Science College (Autonomous) Gobichettipalayam, Tamilnadu. India. Assistant Professor of English, Anna University of Technology,Coimbatore. Tamilnadu, India Research
Journal of English Language and Literature (RJELAL Vol.2.Issue.3.;2014)

[15] Putra S Ichsan, Ariyanti Pratiwi, 2009. Sukses Dengan Soft Skills. Direktorat Pendidikan Institut Teknologi Bandung (ITB)

[16] Evans, Carl, Gbolahan Gbadamosi, Jamie Wells and Ian Scot . Balancing the Yin and Yang: the role of universities in developing softer skills in accountancy INDUSTRY \& HIGHER EDUCATION Vol 26, No 1, February 2012, pp 63-70, doi: 10.5367/ihe.2012.0081 